\title{
Title: Enterprise Social Media Impact on Human Resource Practices
}

\author{
Authors: \\ Godwin Oscar Offong, Bournemouth University \\ Dr Joyce Costello, Bournemouth University
}

Abstract

Purpose:

The purpose of this paper is to investigate how individual attitudes towards using enterprise social media (ESM) impacts trust, explicit and tacit knowledge sharing as well as work performance in emerging economies.

Design/methodology/approach:

The authors use data from a survey of 293 employed individuals in Lagos, Nigeria that work at organizations that have ESM systems.

Findings:

The authors find enterprise social media usage are significantly associated with trust. However, ESM use does not impact explicit or tactic knowledge transfer.

Practical implications:

The paper provides empirical evidence that individuals who perceive high levels of performance expectancy will engage in ESM usage which in turn increases trust amongst colleagues. Human resource managers can argue that by adopting ESM, they can facilitate improved trust and collaboration through online engagement amongst employees. This is important for multinational organizations wanting to expand into emerging economies where the organization and local workforce need to foster trust in knowledge sharing.

Originality/value:

There has been little evidence regarding HRM use of ESM in emerging economies. By understanding individual attitudes towards ESM and how the use impacts knowledge sharing, the academic discussions concerning use of technology to enhance knowledge sharing can continue to evolve.

Keywords: Unified Theory of Acceptance and Use of Technology, Enterprise Social Media, knowledge transfer, trust

Type: Research Paper 


\section{Introduction}

Rapid development in information technology has resulted in many organizations adopting social media as a strategic tool in communicating with internal and external audiences. Human resource departments are increasingly using enterprise social media (ESM) to create social relationships, enhance communication and trust amongst employees. Studies show that the use of electronic networks has been linked to knowledge management (e.g. Alavi and Leidner 2001; Wasko and Faraj 2005) and improved communication and collaboration in order to enhance individual performance at work (North 2010). Furthermore, incorporation of internet technology has proven to impact organizational knowledge transfer and performance (e.g. Hsia et al. 2006; Chatti et al. 2007; Bennet et al. 2010; Leidner et al. 2010; Moqbel et al. 2013).

However, many studies involving the use of technology in the workplace are explored in the America and Western Europe context with HR departments in emerging economies slow to adapt to digital transformations. Some scholars argue that the digital divide is a result of modern telecommunications infrastructures in emerging economies such as sub-Saharan Africa ignoring the necessary development needed for land-lines and focusing on mobile instead (Lee et al. 2012). If individuals don't have access to online systems in the workplace, this may impeded attitudes towards engaging with ESM. Therefore, there is an opportunity to bridge the gap in 
knowledge by exploring in emerging economies if individual attitudes towards ESM and usage will impact on knowledge sharing and performance.

In order to understand these questions, we call upon three theories. Since social interaction is critical to any kind of exchange (Lin 2001), social capital theory proposes that tangible and intangible benefits can be gained through social interactions. This suggests that knowledge transfer can be best achieved through social interactions mediated through the use of ESM tools and technologies (Nahapiet and Ghoshal 1998; Lin 2007). Secondly, media synchronicity theory can be used to explore ESM impact on performance through the conveyance and convergence capacity of media (Dennis and Valacich 1999). Media synchronicity posits that goals are achieved and performance is enhanced when communication needs are supported by the medium used (Dennis et al. 2008). Finally, the unified theory of acceptance and use of technology (UTAUT) explains user perception and subsequent behavior and use of technology. It assumes that performance and effort expectancy directly determine individuals’ usage intensions and behavior (Venkatesh et al. 2003). Together, these theories should assist us in answering if individual attitudes towards ESM use will impact knowledge transfer and performance.

This paper seeks to contribute to academic conversations threefold. First, using the social capital theory (Yoon and Rolland 2012) we examine how the unique collaborative and communicative potentials of ESM can help overcome barriers to knowledge transfer. Secondly, we add empirical evidence linking media synchronicity theory to higher performance at work (Cao et al. 2012). Finally we seek to answer Venkatesh et al.'s (2016) call for new outcome mechanisms such as “new consequences of behavioral intention and technology use added to the original UTAUT” (p. 335). Understanding the impact of ESM use on knowledge transfer 
will enable HR practitioners to effectively address the issues of knowledge transfer amongst individuals, across departments and geographical locations. Limitations and gaps from this study will also be beneficial in directing future research in this field.

\section{Theoretical Framework}

\section{Enterprise Social Media}

ESM is the direct adoption of social media tools that are either public facing (such as a Facebook or LinkedIn page) or organizational facing (such as an intranet, internal wikis or closed Facebook or LinkedIn groups) with the purpose to facilitate communication, connection and collaboration amongst employees (Patroni et al. 2016). ESM can be optional, encouraged or even mandated for employees (Ellison and Boyd 2013). The use of each system differs though. Social media is primarily for social, interpersonal goals and entertainment; whereas, ESM is used to accomplish work related goals and maintaining professional contacts (Ellison and Boyd 2013). Finally, ESM allows for organizational content aggregation which can be used internally as a means of collaboration across silos (Kane 2015) or externally for crowdsourcing ideas or solutions to problems (Alimam et al. 2017).

Kaplan and Heinlein (2010) observed that early adoption and use of ESM was pioneered by employees who independently joined public sites like Myspace and Facebook and interacted with co-workers. Younger, new employees in companies like IBM and Microsoft, who were used to Facebook, used this social media extensively to learn about their new colleagues and create new social relationships (DiMicco and Millen 2007). In addition to socialization, these relationships paved the way for knowledge transfer. Tulgan (2007) suggests that flexible working, socialization, training and development functions can be promoted with ESM tools. Furthermore, various scholars advocate HR use of ESM internally to promote 
organizational citizenship behavior, performance, knowledge management and transfer in the organization (e.g. Nucleus 2009; Bennet et al. 2010; Leidner et al. 2010; Moqbel et al 2013).

ESM is not without criticism though. Nucleus Research (2009) suggests that Facebook use by organizational members' results in over 1.5\% drop in productivity. D'Abate and Eddy (2007) noted that employers feared online activities would lead to cyber-loafing and loss of productivity. From an organizational aspect, Alimam et al. (2017) states that strategic planning and architectural design remains a challenge for organizations considering implementing ESM. Therefore, in order to address the issue of the trade-offs between how the employees elect to use ESM and the IT support needed by a company to develop their own system (non-public source such as IBM’s BeeHive), one must first examine employees attitudes towards using ESM.

\section{Unified Theory of Acceptance and Use of Technology}

Formulated by Venkatesh et al. (2003), UTAUT was developed as a review of the leading technology adoption and acceptance theories in the field of Information Systems, such as the Theory of Reasoned Action, Technology Acceptance Model, and motivational theories. Over the past decade, UTAUT has been largely successful in explaining variance in behavioral intentions and variance in technology use and attempts to explain the various factors that influences at a micro level the individual's intentions and subsequent use of technology in over a thousand studies (Venkatesh et al. 2016). The four constructs that show the determinants of usage intentions and usage behavior are performance expectancy, effort expectancy, social influence and facilitating conditions (Venkatesh et al. 2003). Research shows that 
usage expectancy and effort expectancy are the central constructs of UTAUT and can predict individual intention and behavior (Verhoeven et al. 2010).

Performance expectancy refers to the degree an individual believes that using an information system will aid individuals in attaining gains in their job performance (Venkatesh et al. 2003). If the technology is perceived as useful in performing daily duties, then it is most likely to be adopted by an individual. This construct was found to be the strongest in predicting usage intentions and actual use of technology for eHRM usage (Obeidat 2016). Conversely, effort expectancy refers to the ease of use associated with information system (Venkatesh et al. 2003). It suggests that how straightforward it is to use a new information system, the easier it will be for individuals to do so (Im et al. 2011). Research shows that this is a significant factor at the early stages of adopting new technology, but becomes less effective with sustained and extended use (Wang et al. 2013).

Controls such as gender and age have played an important role in understanding how UTAUT differs (Venkatesh et al. 2016). El Ouirdi et al. (2016) found that being a younger male instead of a female was significantly related to effort expectancy and behavior intention. This was contrary to many other studies which found being a female would influence use (Venkatesh et al. 2016). These findings suggest that in developing or emerging economies that previously dominate moderating factors such as gender may differ then what is commonly found in Western studies. Most theories of technology use have hypothesized age as a moderating factor (Venkatesh et al. 2003; Venkatesh et al. 2012). Morris and Venkatesh (2000) found that an age difference exists when it comes to technological adoption. Posner (1996) attributes a decline in cognitive capabilities that follows the aging process and corresponds to Prensky’s (2001) theory of digital natives and 
digital immigrants, which suggests that people born in the 80's are most comfortable in using technology. This implies that in countries where millennials make up the majority of the workforce, that they should be more comfortable in using ESM. Additionally, research shows that older workers have a harder time adapting to changes in work processes and are likely to take solace in familiar methods (Morris and Venkatesh 2000). This lack of familiarity and comfort in using new technology could inhibit older workers who will have more implicit knowledge from their wealth of experience from engaging in a platform that is favored by younger generations.

Cardon and Marshall (2015) noted that one of the barriers to wide adoption is entrenched habit and organizational cultural realities and individual perceptions. Undoubtedly the perception of the employee to ESM could bear a direct effect on ESM use and its ability to aid either knowledge transfer or performance. A positive perception of ESM could lead to the individual voluntarily using ESM systems. Thus, the following is hypothesized:

Hypothesis 1: Performance and effort expectancy are positively related to ESM usage.

\section{Knowledge Transfer- Social Capital Theory}

The essence of knowledge transfer lies in the provision of expertise, know-how and methods that help members of the organization develop ideas and implement procedures and processes (Wang and Noe 2010). Social capital theory assumes that social relationships are essential to resources and learning (Yoon and Roland 2012). It emphasizes the importance of the relational rather than the technical aspects of the 
organization, which is a strong point of ESM (McAfee 2009). Social capital plays a crucial role in knowledge transfer as ESM enhances these relationships by transcending bureaucratic hierarchies’ and physical boundaries, helping identify expertise and fostering knowledge transfer (Chatti et al. 2007). Ellison et al. (2010) found that ESM facilitated the creation of weak ties where no connections existed, making knowledge transfer more likely. Therefore with ESM, relationships spanning the entire organization are created and maintained aiding the flow of diverse knowledge (Kavanaugh et al. 2005).

However, a major barrier to knowledge sharing is lack of trust amongst colleagues (Fang and Chiu 2010). Trust refers to an individual's capacity to authenticate knowledge received as being relevant and factual, devoid of risks, errors and inconsistencies (Lin 2007). Skinner et al. (2014, p.208) contends that trust is a “process” which focuses on individual pre-conceived beliefs that leads to a decision to trust and culminates in demonstrating ones trust. Fang and Chiu (2010) say trust generally develops overtime via interactions, relationships and experiences. Face-toface interactions, mutual experiences and length of time of familiarity lead to willingness and readiness to share knowledge (Fang and Chiu 2010). While many studies and surveys explore trust between employees and management (Malinen et al. 2013; Kampkotter et al. 2016) or how organizations attempt to regulate employee behaviors as a means of increasing employee trust within the organization (Weibel et al. 2016), trust amongst employees is equally important when it comes to knowledge transfer. This interpersonal trust focuses on the individual be willing to be vulnerable and believe in the positive behavior of their colleagues (De Jong et al. 2016). Trust, a key element of the relational dimension of the social capital theory, has been shown in research and theory to have a positive effect on the knowledge sharing intention 
and behavior of individuals in organizations (Fang and Chiu 2010). ESM use can create and strengthen social networks and interactions which may lead to trust amongst colleagues (Fang and Chiu 2010). Studies about virtual teams and distributed working found that trust was positively associated with knowledge transfer, indicating that virtual team members' interpersonal trust was enhanced by mutual communication and understanding via ESM use (Wu et al. 2006, Chen and Hung 2010). Therefore, it is expected the organizations that adopt ESM that are used by employees can improve trusts amongst themselves.

Hypothesis 2: Use of ESM tools has a positive impact on trust.

A second area of concern is what form of knowledge needs to be transferred: tacit or explicit knowledge (Nonaka 1994). Explicit knowledge refers to knowledge that can be expressed in formal and systematic language and shared in written form e.g. manuals, formulae and specifications (Hsu 2006). Explicit knowledge is coded and articulated, therefore it is relatively easy for knowledge management systems to identify, store and transfer (Nonaka et al. 2000). ESM technologies provide features that enable organizations to effectively store and manage knowledge (Steininger et al. 2010). For example, explicit knowledge sharing involves all the organizations institutionalized and formal knowledge sharing methods and tools like manuals, documents procedures and formulas (Nonaka and Takeuchi 1995). ESM can enhance the availability and access to explicit knowledge especially when made available on organizations intranets, blogs and wikis (Nonaka and Takeuchi 1995). HRM’s use of an intranet can be used to facilitate learning organizational culture (Bennett 2014). Steinfield et al. (2009) examined how IBM’s BeeHive incorporated the creation of 
new social interactions that created linkages to resources within the organization, on or off site at any given time. They observed that this ESM system had an ability to create social capital as well as increase employee engagement and organizational citizenship behavior. With the move to digitalize many HRM aspects, it is imperative that the employees actively use these systems in order to absorb knowledge at an explicit level.

Hypothesis 3: Use of ESM tools has a positive impact on explicit knowledge transfer.

Conversely, tacit knowledge is highly personalized and hard to formalize and may include personal insights, hunches, intuition and feelings (Nonaka and Takeuchi 1995). Tacit knowledge is developed mainly through experiences, routine and emotions (Nonaka et al. 2000). Individuals possess tacit knowledge in the form of technical know-how, experience and insight (Abidi et al. 2005). It is instrumental in improving organizations knowledge base, quality of work, productivity and competitiveness (Nonaka and Takeuchi 1995). The unstructured nature of tacit knowledge makes it difficult to manage and share (McKenzie and Potter 2004). While it is possible to share through traditional methods of face-to-face interactions (apprenticeships and direct observation), the cost involved makes it expedient for alternative methods (Alavi and Leidner 1999), but may provide better interactivity, cooperation and engagement of the recipient (McKenzie and Potter 2004).

ESM can be used to facilitate effective tacit knowledge transfer by enabling relations across organizational silos (Sambamurthy and Subramani 2005). They afford easier and better access to knowledge by creating social connections that 
ensure that originators and recipients communicate and collaborate, even without face-to-face contact (Majchrzak et al. 2005). Abidi et al. (2009), further espouses that ESM can be helpful for tacit knowledge through its collaborative, interactive technologies, allowing for criticism to enhance the quality of experiential knowledge.

However, Haldin-Herrgard (2000) argues that knowledge sharing through the use of ESM is too limited, if not impossible to achieve. It may be possible to facilitate tacit knowledge transfer using ESMs, but it may not be as rich as face-toface interactions in the old systems of knowledge management (Falconer 2006). On the other hand, using blogs, video blogs and wikis are as effective and efficient ways of tacit knowledge transfer as face-to-face communication if not better, due to its ability to replay and be stored for longer while providing access for more employees' organization wide (Khan and Jones 2011). Together, these studies lead us to hypothesize the following.

Hypothesis 4: Use of ESM tools has a positive impact on tacit knowledge transfer.

\section{Performance}

The media synchronicity theory (MST) was developed by Dennis et al. (2008) to explain the role of technology in enhancing employee performance. MST focuses on the capability of information technology to support and enhance synergy and collaboration between individuals working to achieve the same goals (Dennis et al. 2008). It postulates that it is the extent to which the capabilities of a communication medium enable individuals to achieve synchronicity through conveyance and convergence (Dennis et al. 2008). The conveyance process represents the 
transmission of new information and the processing of that information by the recipient in order to create, modify and align one's mental image of the situation (Cao et al. 2012). This process is enhanced by media that is low in synchronicity because it needs cognitive resources to read and understand and then integrate information or knowledge into a mental model. Therefore, lower synchronicity allows more time between message transmissions so recipients can assimilate them better (Cao et al. 2012). With less understanding of the task, media and colleagues involved, communication processes should use the conveyance process with lower media synchronicity (Dennis et al. 2008).

Conversely, the convergence process uses mediums with higher synchronicity which leads to better communication performance. Because information has already been transferred and integrated into the recipients' mental models, therefore the resulting discussion focuses on already conveyed and processed information (Dennis and Valacich 1999). This process involves mutual agreement on the meaning of information and is enhanced by media high on synchronicity, allowing for 'give and take' between sender and recipient in order to arrive at a mutual understanding (Cao et al. 2012). Convergence process will likely be used in a situation where there is a better understanding of the task, the media and colleague, therefore utilizing higher media synchronicity communication (Dennis et al. 2008; Cao et al. 2012).

Moqbel et al. (2013) contend that increased commitment afforded by the use of ESM tools will positively influence job satisfaction and performance of the employer. Other researchers supports this assertion by establishing the use of social media at work was worthwhile, given that it enabled creation of new relationships and sustaining existing relationships (North 2010). Leidner et al. (2010) found that new employees performed better and faster after using the ESM when building new 
relationships and facilitating quick tacit and explicit knowledge transfer. Collective knowledge was improved when using ESM hence contributing to the job performance of the employees (Bennett et al. 2010). Therefore this study hypothesizes the following:

Hypothesis 5: Use of ESM tools has a positive effect on work performance.

Figure 1 depicts our conceptual model.

Insert Figure 1 about here

\section{Method}

\section{Research Context}

While there is a burgeoning group of studies concerning Nigerian universities using social media as knowledge transformation (e.g. ObotEkaNjeze 2012, Fasae and Adegbilero 2016; Quadri and Abebayo 2016), there are no studies to our knowledge on HR's uses of ESM in developing countries of sub-Saharan Africa or Nigeria. With the return of democratic government in Nigeria, foreign investment has increased with large multinational corporations like Google, Samsung, MTN and HP coming into the country for the first time (Amaeshi and Amao 2009). ESM systems are most likely being used in these companies home country and may have proven effective in bridging geographical, social and boundaries to knowledge transfer and performance. With the prevailing social boundaries, ESM tools can help build trust and better social connections, facilitating better communication and performance 
(Leonardi et al. 2013). Therefore, we use a sample of Nigerian employees in order to investigate how ESM use impacts communication, knowledge transfer and performance in emerging economies.

\section{Sample and procedure}

To test our hypotheses, we distributed web-based surveys through HR departments in the public sector, non-profit and multi-national organizations in Lagos, Nigeria. These organizations were chosen as many of the local organizations' private sector HR departments did not actively use social media or ESM to engage with employees. After screening responses for incomplete surveys or unengaged responses, 293 valid respondents were considered for the study. The final population sample consisted of 58\% males. Generation X respondents accounted for 54.3\% and millennials accounted for 41\%. Prensky (2001) highlighted the digital divide when it comes to adopting technology amongst the various generations. Furthermore, generational studies have been increasingly important in HR literature when managing different generations (Lieber 2010). When the data was collected, Millennials were aged 31and younger, Generation X were 32-46 and Baby Boomers were 47-66 (Lieber 2010). Respondents were almost evenly distributed between the multi-national (private) sector and public sector with $47.4 \%$ and $39.2 \%$ respectively, while non-profit sector consisted of $13.3 \%$. Respondents were mostly drawn from middle management level (33.8\%) and closely followed by intermediate level (24.9\%). Middle management has often been associated with efficacy of HRM practices in high-involvement HR systems (Krausert 2014), while intermediate or professional employees do not. The majority (81.2\%) of respondents had worked less than 10 years at their organization and the largest percentage of tenure was two years (14.7\%). Educationally, the majority of respondents (53.9\%) possessed a bachelor's degree. As per the studies 
mentioned in the research context, it is understood that those who possessed a degree probably had a larger exposure to the internet and social media during their studies.

\section{Measures of main variables}

Our dependent variable (DV) knowledge transfer was measured using by Cao et al.'s (2012) nine-item social capital theory scale consisting of dimensions: trust, explicit knowledge and tacit knowledge transfer (Appendix 1). The second DV performance was measured by three validated questions based on media synchronicity theory from Dennis et al. (2008). Our independent variable (IV) used items measuring ESM determinants (i.e. performance expectancy, effort expectancy and use) adopted from Venkatesh et al. (2003) UTAUT model. All scales used a 5-point Likert scale where 1 is strongly disagree and 5 is strongly agree.

\section{Control variables}

Respondents were asked to indicate their biological gender (male $=0$, female $=1$ ), age, education level, job level, tenure and sector of employment. This information was necessary for the research as prior research indicates that age, gender and experience moderate the acceptance and use of technology (Venkatesh et al. 2003). Tenure was measured in years. Dummy variables were created for education (Bachelors: $0=$ no, $1=$ yes), job level (middle management $0=$ no, $1=$ yes) and sector (private (multinational): $0=$ no, $1=$ yes). Age was divided into generations as mentioned above and dummy variables were created for each $(1=$ yes, $0=$ no).

Measurement quality and data analysis

After the data was screened to ensure compatibility with SEM assumptions, a confirmatory factor analysis (CFA) was conducted to test the internal consistency of 
observed items in order to determine adequate measurement model. CFA assumes that the data obtained fits the hypothesized model developed in theory (Hu and Bentler 1999). The standardized coefficients all had values between 0.691 and 0.853 which conformed to Hair et al.’s (2010) recommended value of 0.50 for each item. We conducted a CFA with results confirming the proposed structure (Table 1 and 2). The analysis of the measurement model fit met Hair et al.’s (2010) recommended matrices. Therefore, the proposed model provided a good fit. Composite reliability were all higher than .60 and the average variance extracted (AVE) was all above .50.

Insert Table 1 and Table 2 about here

Common method bias (CMB) was tested using a zero-constraint approach to see if the shared variance across all items were significantly different than zero by conducting a chi-squared difference test. The unconstrained model had a Chi-square= 1.662 and $\mathrm{df}=4$, while the fully constrained (zero constrained) model had had a Chisquare $=8.406$ and $\mathrm{df}=11$. As the $\mathrm{p}$-value $=.456$, it was invariant and therefore no evidence of CMB was present (Podsakoff et al. 2013). A multicollinearity test for the DVs showed the mean variance inflation factor (VIF) is less than three with the single highest VIF as 1.855 and thus acceptable (Hair 2010). The descriptive analysis (table 3) shows the correlations amongst all variables (IV, DV and controls) and reveals that there are high associations amongst variables.

Insert Table 3 about here 


\section{Analysis and results}

Structural equation modelling (SEM) was used to test the research model. The major advantages of SEM over traditional methods includes the ability to test complex models with more accuracy, simultaneous analysis of multiple variables and a visual representation of models that is translated into mathematical equations needed for analysis (Byrne 2011). In order to achieve an acceptable goodness of fit of the structural model, DV performance had to be deleted due to modification indices existing between performance and IV effort expectancy. While it is acceptable to covary error terms, it is inacceptable to covary between observed and latent variables (Byrne 2011). This means we were unable to test our hypothesis concerning performance. The assessment of the full structural model demonstrated a goodness of fit $[$ Chi-square/df $(\mathrm{CMIN} / \mathrm{DF})=2.349$; Goodness of fit index $(\mathrm{GFI})=.944$; Adjusted goodness of fit index $(\mathrm{AGFI})=.914$; root mean square error of approximation $($ RMSEA $)=0.068$ and PCLOSE $=.043]$. When using only knowledge transfer variable explicit as an outcomes it demonstrated a better fit then the complete model: $\mathrm{CMIN} / \mathrm{DF}=1.599 ; \mathrm{GFI}=0.970 ; \mathrm{AGFI}=0.948 ; \mathrm{RMSEA}=0.045$ and $\mathrm{PCLOSE}=.591$. When using only knowledge transfer variable tacit as an outcomes it also demonstrated a better fit then the complete model: CMIN/DF= 1.694; GFI=0.969; AGFI=0.946; RMSEA=0.049 and PCLOSE $=$.503. Even when using only trust as an outcome, it demonstrated a good fit: CMIN/DF = 2.375; GFI=0.957; AGFI=0.926; RMSEA $=0.069$ and PCLOSE $=.079$. 
The results of the final structure model (shown in figure 2 and table 4) show that expectancy factors significantly influence use which in turn impacts explicit knowledge and performance.

Insert Figure 2 and Table 4 about here

Hypothesis 1 expects performance and effort expectancy to positively affect use of ESM while at work. Effort expectance as measured by perceived usefulness proved to be a good predictor of ESM use $(\beta=.359, \mathrm{p}<.001)$, but perceived ease of use was insignificant $(\beta=.060, \mathrm{p}=.408)$. The model accounted for $18.4 \%$ of the variance in ESM use and resulted in partial support for H1.

Hypothesis 2 expects ESM use to have a positive impact on trust. ESM use was a good predictor of trust $(\beta=.141 \mathrm{p}<.05)$, but the model accounted for only $2 \%$ of the variance in trust. Thus, $\mathrm{H} 2$ is supported.

Hypothesis 3 expects ESM use to have a positive impact on explicit knowledge. However, ESM use was not a good predictor of explicit knowledge ( $\beta$ $=.074, \mathrm{p}=.204)$, and the model accounted for only $.6 \%$ of the variance in explicit knowledge. Hence, there is no evidence that H3 is supported. Hypothesis 4 expects ESM use to have a positive impact on tacit knowledge. However, use was not a good predictor of tacit knowledge $(\beta=.027 \mathrm{p}=.640)$ and the model accounted for $.1 \%$ of the variance in trust. Accordingly, $\mathrm{H} 4$ is rejected. 


\section{Discussion}

This paper aimed to answer the question of how individuals' use of ESM could impact knowledge transfer and performance. The intent was to further the discussion in HRM literature as to how ESM impacts employees in Nigeria. We found evidence that performance expectancy positively impacted ESM use, thus complementing numerous other western studies findings (Venkatesh et al. 2016). The logic is that if one expects ESM to improve their performance then it would lead to use. However, that effort expectancy was not related to ESM use was unexpected. This could be due to the sample in emerging economy having other priorities in organizations that may not be resource rich in access to IT and technology.

Unlike many UTAUT studies (Venkatesh et al. 2016), the majority of the controls were not significant. Age did not influence ESM use unlike Morris and Venkatesh (2000) study which suggests that age influenced the adoption of technology or Prensky’s (2001) study which states younger people having a more positive attitude to learning new technology. Since technology has boomed in the last decade in the Nigerian education sector, age was expected to be a significant influence on this relationship (Awoleye et al. 2008). However, those at the lower level of tenure were significantly related to usage. This conforms to Leidner et al. (2010) study that found new employees performed better when ESM tools were used to help them form new relationships and access stored knowledge. It could be that collectively, new hires had developed technological skills regardless of age. Gender, however, was also not significant which is at odds with Morris and Venkatesh`s (2000) and Cao et al.'s (2012) finding that gender has a significant influence on this relationship. Finally, with an increasing amount of Nigerian Millennials using social media during their university studies (Faese et al. 2016), it was unclear why it is not 
being used more so at work. One possibility is that Nigerian HR departments are using ESM in its basic form of an intranet and have not used it in a manner that facilitates engagement and knowledge sharing, such as wikis, chat forums or interactive social sites. Alternatively, as the majority of private internet usage in Nigeria is via mobile, it could be that individuals prefer to use their data plan towards online activities that are of a personal nature opposed to using their data plan to conduct work.

When exploring ESM use and how it impacted knowledge transfer, ESM use was significantly related to trust, but not explicit or tacit knowledge. This implies that the current ESM use has been identified by the respondents as not being vital in facilitating knowledge transfer in their organizations, but possible further ESM adoption may be! The significant relation between ESM usage and trust is supported with Lin’s (2007) and Joia and Lemos’s (2010) studies which emphasized the role of ESM in building trust necessary for social interactions and relationships which drive knowledge transfer. Intangibly, the social network aspect of ESM use help create social relationships where one did not exist (weak ties) and also strengthen existing ties, increasing the potentials for social capital (Bennet et al.2012). Social network tools use has been validated as a strong tool for building trust, which is the major factor in knowledge transfer. Therefore HR use of these tools could increase trust, making it easier to connect to sources of knowledge in the organization (Ellison et al. 2014).

As noted earlier, tacit knowledge is inherent in people and difficult to transfer in organizations (Nonaka and Takeushi 1995). Results do not supported the notion that ESM use (in its current form) by HR departments in Nigeria can overcome these problems to improve tacit knowledge sharing. Our findings fail to corroborate 
Sambamurthy and Subrami's (2005) view that ESM enhances knowledge transfer in organizations through effective access and most importantly through social connections (Majchrzak et al. 2005). Looking back at the main ESM assumptions adopted in this study, the affordance approach by Leonardi and Barley (2008) stated that ESM aids knowledge transfer through social networks, sharing, collaboration and authoring. On the other hand, the assumptions of social capital theory that relationships create tangible benefits (Choi et al. 2014) was emphasized and supported by results which show that respondents mostly used ESM to create and sustain relationships. In the Nigerian context of ESM, HR use and knowledge transfer results do not support affordances and are not consistent with the assumptions of the social capital theory.

Finally, there was no evidence that ESM usage was significantly related to explicit knowledge transfer. Cao et al.’s (2012) study, found that ESM use was more significant on tacit knowledge transfer rather than explicit knowledge. However, in this study- neither explicit nor tacit knowledge was related ESM usage. It could be that Nigerian HR departments have only emphasized organizational material on intranets (which most employees may be reluctant to read) and are limited in their use of ESM tools on wikis or blogs.

As with all research, this study is not without limitations. One area that should have been taken into consideration was the types of ESM system in place at the respondents work and if they accessed it during their workday or on their own time. For example, organizations that rely on ESM tools such as an intranet may improve explicit knowledge, but would not be able to provide an arena for engagement that is needed for tacit knowledge sharing. Secondly, by understanding the type of system in place, the authors might have been able to discover why there 
was a stronger link between ESM uses for trust opposed to explicit or tacit knowledge. Additionally, understanding the context of how the respondents accessed the ESM, may serve to provide a better understanding about the actual adoption habits and access. This is especially important in emerging economies that rely primarily on mobile as means to access the internet as official organizational knowledge transfer documents could suffer from poor responsive design of a standard intranet designed for desktop usage opposed to mobile optimization. Finally, because this was a web-based survey, this may have alienated potential respondents who prefer to not use the web. Therefore, future research recommendations include looking at how individuals access and in what manner.

\section{Conclusions}

In summary, our empirical results suggest that ESM use does impact trust when it comes to knowledge transfer. This paper contributed to our theoretical understanding by providing empirical evidence surrounding social capital theory and how ESM can improve knowledge sharing. Additionally, we answer Venkatesh et al.’s (2016) call for new outcome mechanisms when using UTAUT with our incorporation of knowledge transfer and performance.

These tools can help HR to reach to distributed locations of the organization cheaply and more effectively (Yoon and Roland 2012). This means that teams can work together and exchange information across spatiotemporal barriers as ESM helps to blur barriers between departments and locations (Ellison et al. 2014). Finally, Nigerian HR should recognize that young Nigerians are used to social media will also expect to use these tools at work to enhance learning, socialization and performance. Therefore, HR should use these tools to the organizations advantage 
and provide wikis and blogs to capture organizational knowledge. This will also help HR to make visible the organizations expertise and make it accessible to those who need it. Additionally through the monitoring of active usage, HR can also recognize talent in the work force and take steps to develop and nurture them. 


\section{References}

Abidi, S., Cheah, Y. \& Curran, J. (2005). A Knowledge Creation Info-Structure to Acquire and Crystallize the Tacit Knowledge of Health-Care Experts. IEEE Transactions on Information Technology in Biomedicine 9(2), 193-204.

Abidi, S., Hussini, S., Sriraj, W., Thienthong, S. \& Finley, G. (2009). Knowledge sharing for pediatric pain management via a Web 2.0 framework. Studies in Health Technology \& Informatics 150, 287-291.

Alavi, M. \& Leidner, D. (1999). Knowledge Management SystESM: Issues, Challenges, and Benefits. Commun. AIS 1(2es). Available http://dl.acm.org/citation.cfm?id=374116.374117.

Alavi, M. \& Leidner, D. (2001). Review: Knowledge Management \& Knowledge Management SystESM: Conceptual Foundations \& Research Issues. MIS Quarterly 25(1), 107-136.

Alimam, M., Bertin, E., \& Crespi, N. (2017). Review: ITIL perspective on enterprise social media. International Journal of Information Management, 37, 317-326.

Amaeshi, K. \& Amao, O. (2009). Corporate Social Responsibility in Transnational Spaces: Exploring Influences of Varieties of Capitalism on Expressions of Corporate Codes of Conduct in Nigeria. Journal of Business Ethics 86(S2), 225-239.

Awoleye, M., Siyanbola, O. \& Oladipo, F. (2008). Adoption Assessment of Internet Usage Amongst Undergraduates In Nigeria Universities -A Case Study Approach. Journal of technology management \& innovation 3(1), 84-89.

Bennett, E. E. (2014). How an intranet provides opportunities for learning organizational culture: Implications for virtual HRD. Advances in Developing Human Resources, 16(3), 296-319.

Bennett, J., Owers, M., Pitt, M. \& Tucker, M. (2010). Workplace impact of social networking. Property Management 28(3), 138-148.

Byrne, B. M. (2010). Structural equation modeling with AMOS: basic concepts, applications, \& programming. New York: Routledge, 2nd ed.

Cao, X., Vogel, D., Guo, X., Liu, H. \& Gu, J. (2012). Understanding the Influence of Social Media in the Workplace: An Integration of Media Synchronicity \& Social Capital Theories. 2012 45th Hawaii International Conference on System Sciences.

Cardon, P. \& Marshall, B. (2015). The Hype \& Reality of Social Media Use for Work Collaboration \& Team Communication. International Journal of Business Communication. 52 (3) 273-293.

Chatti, M., Klamma, R. \& Jarke, M. (2007). The Web 2.0 driven SECI model based learning process. In: proceedings of the 7th IEEE International Conference on Advanced Learning Technologies. Niigata. 
Chen, C. \& Hung, S. (2010). To give or to receive? Factors influencing members' knowledge sharing \& community promotion in professional virtual communities. Information \& Management 47(4), 226-236.

Choi, N., Huang, K., Palmer, A. \& Horowitz, L. (2014). Web 2.0 Use \& Knowledge Transfer: How Social Media Technologies Can Lead to Organizational Innovation. The Electronic Journal of Knowledge Management 12(3), 176-186.

D'Abate, C. \& Eddy, E. (2007). Engaging in personal business on the job: Extending the presenteeism construct. Human Resource Development Quarterly 18(3), 361-383.

De Jong, B. A., Dirks, K. T., \& Gillespie, N. (2016). Trust and team performance: A meta-analysis of main effects, moderators, and covariates. Journal Of Applied Psychology, 101(8), 1134-1150.

Dennis, A. \& Valacich, J. (1999). Rethinking media richness: towards a theory of media synchronicity. In: 32nd Annual Hawaii International Conference.

Dennis, A., Fuller, R. \& Valacich, J. (2008). Media, tasks, \& communication processes: A theory of media synchronicity. MIS Quarterly 32, 575-600.

DiMicco, J. \& Millen, D. (2007). Identity management: multiple presentations of self in Facebook. Available at:

http://onemvweb.com/sources/sources/multiple_presentation_facebook.pdf

Ellison, N. \& Boyd, d. (2013). Sociality through social network sites. In: Dutton, W. ed. The Oxford handbook of internet studies. 1st ed. Oxford, UK: Oxford University Press., 151-172.

Ellison, N., Gibbs, J. \& Weber, M. (2014). The Use of Enterprise Social Network Sites for Knowledge Sharing in Distributed Organizations: The Role of Organizational Affordances. American Behavioral Scientist 59(1), 103-123.

Ellison, N., Lampe, C. \& Steinfield, C. (2010). With a little help from my friends: How social network sites affect social capital processes. In: Papacharissi, Z. ed. A networked self: Identity, community, \& culture on social network sites. 1st ed. New York: Routledge.

El Ouirdi, M., El Ouirdi, A., Segers, J., \& Pais, I. (2016). Technology adoption in employee recruitment: The case of social media in Central \& Eastern Europe. Computers in Human Behavior. 57, 240-249.

Fasae, J. K., \& Adegbilero-Iwari, I. (2016). Use of social media by science students in public universities in Southwest Nigeria. The Electronic Library, 34(2), 213-222.

Falconer, L. (2006). Organizational learning, tacit information, \& e -learning: a review. The Learning Organization 13(2), 140-151.

Fang, Y. \& Chiu, C. (2010). In justice we trust: Exploring knowledge-sharing continuance intentions in virtual communities of practice. Computers in Human Behavior 26(2), 235-246. 
Hair, J., Anderson, R., Tatham, R. \& Black, W. (1998). Multivariate Data Analysis, 5th ed. Upper saddle River, NJ: Prentice Hall.

Haldin -Herrgard, T. (2000). D

organizations. Journal of Intellectual Capital 1(4), 357-365.

Hsia, Z., Lin, M., Wu, J. \& Tsai, H. (2006). A framework for designing nursing knowledge management systESM. Interdisciplinary Journal of Information, Knowledge, \& Management 1, 14-21.

Hsu, I. (2006). Enhancing employee tendencies to share knowledge-Case studies of nine companies in Taiwan. International Journal of Information Management 26(4), 326-338.

Hu, L. \& Bentler, P. (1999). Cutoff criteria for fit indexes in covariance structure analysis: Conventional criteria versus new alternatives. Structural Equation Modeling: A Multidisciplinary Journal 6(1), 1-55.

Im, I., Hong, S. \& Kang, M. (2011). An international comparison of technology adoption. Information \& Management 48(1), 1-8.

Joia, L. \& Lemos, B. (2010). Relevant factors for tacit knowledge transfer within organisations. Journal of Knowledge Management 14(3), 410-427.

Kampkötter, P., Mohrenweiser, J., Sliwka, D., Steffes, S. \& Wolter, S. (2016).

Measuring the use of human resources practices and employee attitudes: The Linked Personnel Panel, Evidence-based HRM: a Global Forum for Empirical Scholarship, 4 (2), 94-115.

Kane, G. C. (2015). Enterprise Social Media: Current Capabilities and Future Possibilities. MIS Quarterly Executive, 14(1), 1-16.

Kaplan, A. \& Haenlein, M. (2010). Users of the world, unite! The challenges \& opportunities of Social Media. Business Horizons 53(1), 59-68.

Kavanaugh, A., Reese, D., Carroll, J. \& Rosson, M. (2005). Weak Ties in Networked Communities. The Information Society 21(2), 119-131.

Khan, O. \& Jones, N. (2011). Harnessing tacit knowledge for innovation creation in multinational enterprises: an internal social network approach. JIBED 5(3), 232.

Krausert, A. (2014). HRM systems for knowledge workers: Differences among top managers, middle managers, and professional employees. Human Resource Management 53(1), 67-87.

Lee, S., Levendis, J. \& Gutierrez, L. (2012). Telecommunications and economic growth: an empirical analysis of sub-Saharan Africa, Applied Economics 44(4), 461469.

Leidner, D., Koch, H. \& Gonzalez, E. (2010). Assimilating Generation Y IT New Hires into USAA's Workforce: The Role of an Enterprise 2.0 System. MIS Quarterly Executive 9(4). 229-242. 
Leonardi, P. \& Barley, S. (2008). Materiality \& change: Challenges to building better theory about technology \& organizing. Information \& Organization 18(3), 159-176.

Leonardi, P., Huysman, M. \& Steinfield, C. (2013). Enterprise Social Media: Definition, History, \& Prospects for the Study of Social Technologies in Organizations. Journal of Computer-Mediated Communication. 19(1), 1-19.

Lieber, L. D. (2010). How HR can assist in managing the four generations in today's workplace. Employment Relations Today 36(4), 85-91.

Lin, C. (2007). To Share or Not to Share: Modeling Tacit Knowledge Sharing, Its Mediators \& Antecedents. Journal of Business Ethics 70(4), 411-428.

Lin, N. (2001). Social capital: A theory of social structure \& action. Cambridge: Cambridge University Press.

Majchrzak, A., Malhotra, A. \& John, R. (2005). Perceived Individual Collaboration Know-How Development Through Information Technology-Enabled Contextualization: Evidence from Distributed Teams. Information SystESM Research 16(1), 9-27.

Malinen, S., Wright, S. \& Cammock, P., (2013) What drives organisational engagement?: A case study on trust, justice perceptions and withdrawal attitudes, Evidence-based HRM: a Global Forum for Empirical Scholarship, 1(1), 96-108.

McAfee, A. (2009). Enterprise 2.0 How a Connected Workforce Innovates. Harvard Business Review. 87(12) 80-81.

McKenzie, J. \& Potter, R. (2004). Enabling conditions for virtual tacit knowledge exchange. In: Truch, E. ed. Leveraging corporate knowledge. The Gower Developments in Business Series. 1st ed. Aldershot: Gower, 89-116.

Moqbel, M., Nevo, S. \& Kock, N. (2013). Organizational members' use of social networking sites \& job performance. Information Technology \& People 26(3), 240264.

Morris, M. \& Venkatesh, V. (2000). Age Differences in Technology Adoption Decisions: Implications for A Changing Work Force. Personnel Psychology 53(2) 375-403.

Nahapiet, J. \& Ghoshal, S. (1998). Social Capital, Intellectual Capital, \& the Organizational Advantage. Academy of Management Review 23(2), 242-266.

Nonaka, I. \& Takeuchi, H. (1995). The knowledge-creating company. New York: Oxford University Press.

Nonaka, I., Toyama, R. \& Konno, N. (2000). SECI, Ba \& Leadership: a Unified Model of Dynamic Knowledge Creation. Long Range Planning 33(1), 5-34.

Nonaka, I. (1994). A Dynamic Theory of Organizational Knowledge Creation. Organization Science 5(1), 14-37. 
North, M. (2010). An evaluation of employees' attitudes toward social networking in the workplace. Issues in Information SystESM 11(1), 192-197.

Nucleus Research, (2009). Facebook: Measuring the Cost to Business of Social Networking. Boston, MA: Nucleus Research Inc, Boston, MA.

Obeidat, S. M. (2016). The link between e-HRM use \& HRM effectiveness: An empirical study. Personnel Review, 45(6), 1281-1301.

ObotEkaNjeze, M. (2012). Use of Social Media by Researchers in Select Nigerian Universities: A Study. Journal of Library \& Information Science, 37(2), 19-33.

Patroni, J., Von Briel, F. \& Recker, J., (2016). How Enterprise Social Media Can Facilitate Innovation. IT Professional, IT Prof, (6), 34-41.

Podsakoff, N. P., Whiting, S. W., Welsh, D. T. \& Mai, K. M., (2013). Surveying for "artifacts": the susceptibility of the OCB-performance evaluation relationship to common rater, item, \& measurement context effects. The Journal of Applied Psychology, 98 (5), 863-874.

Posner, R. (1996). Aging \& old age. Chicago: University of Chicago Press.

Prensky, M. (2001). Digital Natives, Digital Immigrants Part 1. On the Horizon 9(5), 1-6.

Quadri, G. O., \& Adebayo Idowu, O. (2016). Social Media Use by Librarians for Information Dissemination in Three Federal University Libraries in Southwest Nigeria. Journal of Library \& Information Services in Distance Learning, 10(1/2), 30-40.

Sambamurthy, V. \& Subramani, M. (2005). Special Issue on Information Technologies \& Knowledge Management. MIS quarterly 29(1), 1-7.

Skinner, D., Dietz, G., \& Weibel, A. (2014). The dark side of trust: When trust becomes a 'poisoned chalice'. Organization, 21(2), 206-224

Steinfield, C., DiMicco, J., Ellison, N. \& Lampe, C. (2009). Bowling Online: Social Networking \& Social Capital within the Organization. In: Proceeding C\&T '09 Proceedings of the fourth international conference on Communities \& technologies.

Steininger, K., Ruckel, D., Dannerer, E. \& Roithmayr, F. 2010. Healthcare knowledge transfer through a web 2.0 portal: an Austrian approach. International Journal of Healthcare Technology \& Management. 11(1/2), 13.

Tulgan, B.(2007). Finding roles for social -Stredieg todHRin HR. Review 6(2), 3-3.

Venkatesh, V., Morris, M., Davies, G. \& Davis, F. (2003). User acceptance of information technology: toward a unified view. MIS Quarterly. 27(3), 425-478. 
Venkatesh, V., Thong, J. \& Xu, X. (2012). Consumer Acceptance \& Use of Information Technology: Extending the Unified Theory of Acceptance \& Use of Technology. MIS Quarterly, 36 (1)157-178.

Venkatesh, V., Thong, J. Y. L., \& Xin, X. (2016). Unified Theory of Acceptance \& Use of Technology: A Synthesis \& the Road Ahead. Journal of the Association for Information SystESM, 17(5), 328-376.

Verhoeven, J., Heerwegh, D. \& De Wit, K. (2010). Information \& communication technologies in the life of university freshmen: An analysis of change. Computers \& Education 55(1), 53-66.

Wang, J., Tian, J. \& Shen, Z. (2013). The effects \& moderators of cyber-loafing controls: an empirical study of Chinese public servants. Information Technology \& Management 14(4), 269-282.

Wang, S. \& Noe, R. (2010). Knowledge sharing: A review \& directions for future research. Human Resource Management Review 20(2), 115-131.

Wasko, M. \& Faraj, S. (2005). Why Should I Share? Examining Social Capital \& Knowledge Contribution in Electronic Networks of Practice. MIS Quarterly 29(1), 35-57.

Weibel, A., Den Hartog, D. N., Gillespie, N., Searle, R., Six, F., \& Skinner, D. (2016). How do controls impact employee trust in the employer? Human Resource Management, 55(3), 437-462.

Wu, S., Lin, C. \& Lin, T. (2006). Exploring Knowledge Sharing in Virtual Teams: A Social Exchange Theory Perspective. Proceedings of the 39th Annual Hawaii International Conference on System Sciences. Kauia.

Yoon, C. \& Roll\&, E. (2012). Knowledge-sharing in virtual communities: familiarity, anonymity \& self-determination theory. Behaviour \& Information Technology 31(11), 1133-1143. 


\section{Appendices- Tables}

Table 1: Confirmatory Factor Analysis

\begin{tabular}{llrrrcc}
\hline & Items & $\begin{array}{l}\text { Factor } \\
\text { Loading }\end{array}$ & $\begin{array}{l}\text { Error } \\
\text { Variance }\end{array}$ & t-value & $\begin{array}{l}\text { composite } \\
\text { reliability }\end{array}$ & $\begin{array}{l}\text { average } \\
\text { variance } \\
\text { extracted }\end{array}$ \\
\hline Criteria & & $.5-.97$ & nogative & $>1.96$ & $>.6$ & $>.5$ \\
\hline Performance & PU1 & 0.691 & 0.503 & 9.541 & 0.687 & 0.524 \\
expectancy & PU2 & 0.755 & 0.377 & 8.014 & & \\
\hline Effort & EASE1 & 0.853 & 0.241 & 5.319 & 0.767 & 0.624 \\
expectancy & EASE2 & 0.721 & 0.391 & 9.294 & & \\
\hline Use & USE1 & 0.846 & 0.438 & 7.896 & & \\
Behavior & USE2 & 0.852 & 0.363 & 7.709 & 0.885 & 0.720 \\
& USE3 & 0.848 & 0.343 & 7.857 & &
\end{tabular}


Table 2: Comparison between fit criteria and results of the model

\begin{tabular}{|c|c|c|c|}
\hline & Measurement Items & Criteria & Results \\
\hline \multirow{2}{*}{$\begin{array}{l}\text { Preliminary } \\
\text { Fit Criteria }\end{array}$} & Factor Loading & $.5-.97$ & Compliant \\
\hline & Error Variance & $\begin{array}{l}\text { non- } \\
\text { negative }\end{array}$ & Compliant \\
\hline \multirow{2}{*}{$\begin{array}{c}\text { Fit of } \\
\text { internal } \\
\text { structure of } \\
\text { model } \\
\end{array}$} & Composite reliability & $>.6$ & Compliant \\
\hline & Average variance extracted & $>.5$ & Compliant \\
\hline \multirow{4}{*}{$\begin{array}{c}\text { Overall } \\
\text { Model Fit }\end{array}$} & ¿2/d.f.(normed Chi-square) & $<3$ & Compliant (CMIN/DF .764) \\
\hline & Goodness of fit index (GFI) & $>.8$ & Compliant (GFI .992) \\
\hline & Adjusted goodness of fit index (AGFI) & $>.8$ & Compliant (AGFI .980) \\
\hline & Root mean square Residual (RMSEA) & $<.05$ & Compliant (RMSEA .000, PCLOSE = .954) \\
\hline
\end{tabular}


Table 3: Descriptive analysis

\begin{tabular}{|c|c|c|c|c|c|c|c|c|c|c|c|c|c|}
\hline \multicolumn{14}{|c|}{ Correlations } \\
\hline & Mean & S.D. & 1 & 2 & 3 & 4 & 5 & 6 & 7 & 8 & 9 & 10 & 11 \\
\hline $\begin{array}{l}\text { 1 Performance } \\
\text { Expectancy }\end{array}$ & 3.94 & .838 & & & & & & & & & & & \\
\hline $\begin{array}{l}2 \text { Effort } \\
\text { Expectancy }\end{array}$ & 3.97 & .829 & $.679^{* *}$ & & & & & & & & & & \\
\hline 3 Usage & 3.48 & 1.053 & $.409^{* *}$ & $.323^{* *}$ & & & & & & & & & \\
\hline 4 Trust & 3.42 & .982 & $.250^{* *}$ & $.206^{* *}$ & $.142^{*}$ & & & & & & & & \\
\hline 5 Explicit & 3.25 & .939 & -.025 & -.095 & .075 & $.197^{* *}$ & & & & & & & \\
\hline 6 Tacit & 3.74 & .716 & .017 & $.137^{*}$ & .027 & .065 & .111 & & & & & & \\
\hline 7 Performance & 3.71 & .740 & $.362^{* *}$ & $.434^{* *}$ & $.327^{* *}$ & $.273^{* *}$ & .014 & $.248^{* *}$ & & & & & \\
\hline 8 Gender & .42 & .494 & .014 & -.035 & .020 & $-.122^{*}$ & -.051 & -.072 & -.092 & & & & \\
\hline 9 Millennial & .41 & .493 & .049 & .056 & .103 & -.042 & .019 & -.012 & .085 & .079 & & & \\
\hline 10 Middle Mgt & .31 & .462 & .090 & .101 & .060 & .020 & .039 & -.067 & .030 & -.087 & $-.133^{*}$ & & \\
\hline 11 Education (BA) & .56 & .497 & .049 & .092 & -.017 & $.120^{*}$ & .047 & -.010 & $.137^{*}$ & .002 & .012 & -.035 & \\
\hline 12 Years & 6.96 & 6.027 & -.088 & $-.174^{* *}$ & $-.177^{* *}$ & $.117^{*}$ & .069 & .001 & $-.122^{*}$ & -.109 & $-.476^{* *}$ & .001 & -.066 \\
\hline
\end{tabular}

**. Correlation is significant at the 0.01 level (2-tailed). *. Correlation is significant at the 0.05 level (2-tailed).

Note $*$ S.D. $=$ Standard Deviation, Observations $=$

293 
Table 4: Hypotheses testing results

\begin{tabular}{|c|c|c|c|c|c|c|}
\hline \multicolumn{2}{|l|}{ Hyp. } & \multicolumn{2}{|l|}{ Path } & \multicolumn{2}{|l|}{$\begin{array}{c}\text { Standardized } \\
\text { Estimate } \beta\end{array}$} & \multirow{2}{*}{$\begin{array}{l}\text { Support } \\
\text { Yes }\end{array}$} \\
\hline H1 & Usage & $<---$ & $\begin{array}{l}\text { Performance } \\
\text { Expectancy }\end{array}$ & $0.359 * * *$ & 0.090 & \\
\hline & Usage & $<---$ & $\begin{array}{l}\text { Effort } \\
\text { Expectancy }\end{array}$ & 0.060 & 0.091 & No \\
\hline & Usage & $<---$ & Millennial & 0.025 & 0.128 & \\
\hline & Usage & $<---$ & Gender & 0.004 & 0.112 & \\
\hline & Usage & $<---$ & Middle Mgt & 0.024 & 0.120 & \\
\hline & Usage & $<---$ & Education BA & -0.048 & 0.111 & \\
\hline & Usage & $<---$ & Years & $-0.127 *$ & 0.010 & \\
\hline $\mathrm{H} 2$ & Trust & $<---$ & Usage & $0.141^{*}$ & 0.054 & Yes \\
\hline H3 & Explicit & $<---$ & Usage & 0.074 & 0.052 & No \\
\hline $\mathrm{H} 4$ & Tacit & $<---$ & Usage & 0.027 & 0.040 & No \\
\hline
\end{tabular}


Figures:

Figure 1: Conceptual Model

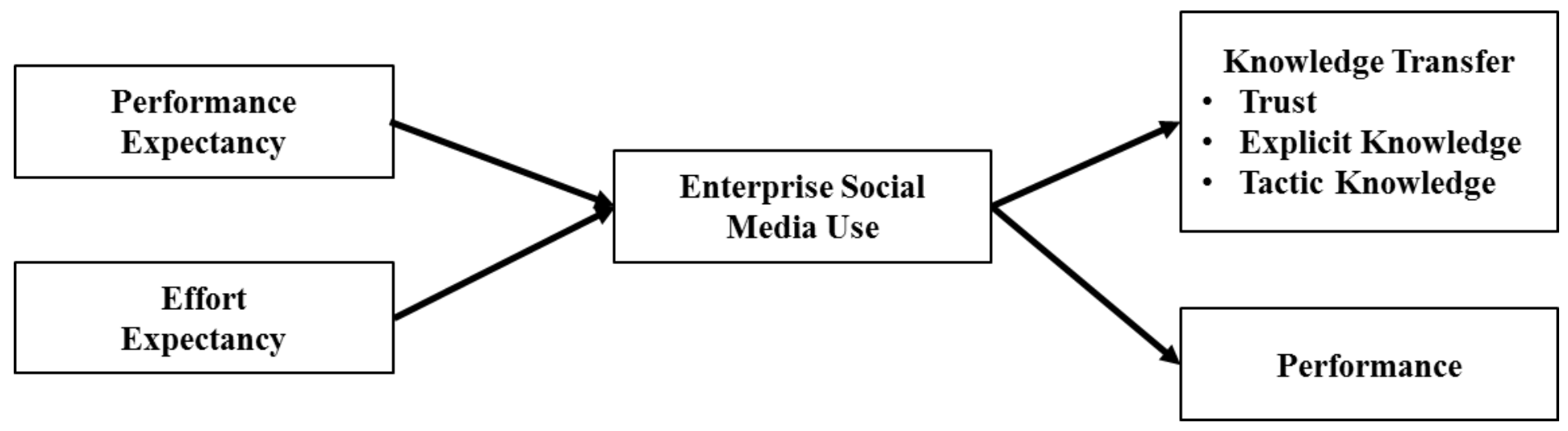


Figure 2: Structural Model

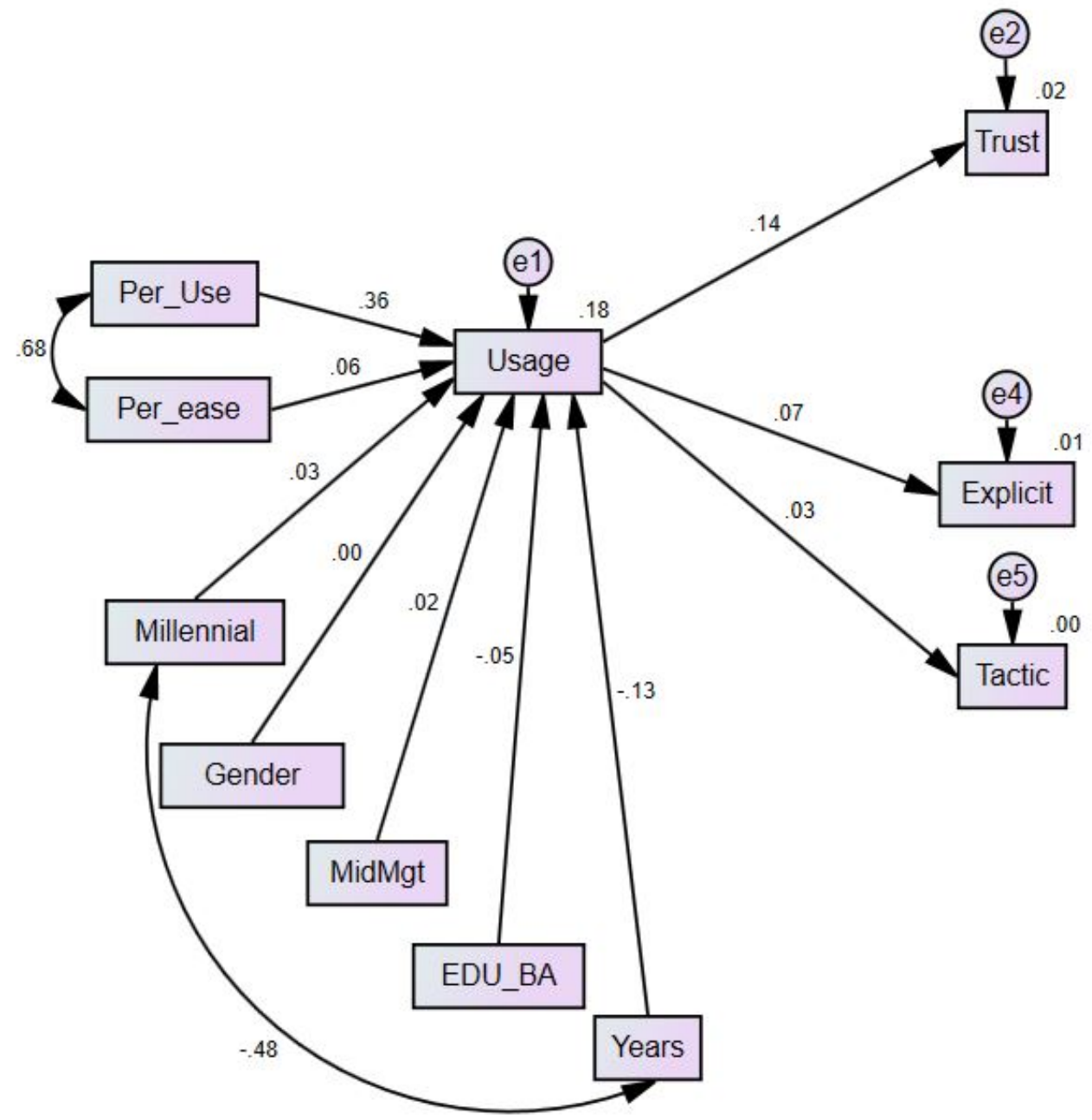

Note: Per_Use= Performance Expectancy; Per_ease= Effort Expectancy; Usage= Enterprise Social Media Actual Use; MidMgt= middle management (1=yes, 0=no); EDU_BA= Education at Bachelors level $(1=$ yes, $0=$ no); Millennial= respondents aged middle management ( $1=$ yes, $0=$ no); 


\begin{tabular}{|c|c|c|c|}
\hline THEORY & CONSTRUCT & QUESTIONS & SOURCE \\
\hline \multirow{6}{*}{$\begin{array}{l}\text { Unified Theory Of } \\
\text { Acceptance And } \\
\text { Use Of Technology }\end{array}$} & Effort Expectancy & $\begin{array}{l}\text { Learning to operate my } \\
\text { workplace social media will } \\
\text { be easy for me } \\
\text { It will be easy to become } \\
\text { skillful at using this social } \\
\text { media system }\end{array}$ & \multirow{6}{*}{$\begin{array}{l}\text { Venkatesh et } \\
\text { al. } 2003\end{array}$} \\
\hline & \multirow[t]{2}{*}{$\begin{array}{l}\text { Performance } \\
\text { Expectancy }\end{array}$} & $\begin{array}{l}\text { Using the workplace social } \\
\text { media will help me } \\
\text { accomplish tasks faster and } \\
\text { more efficiently }\end{array}$ & \\
\hline & & $\begin{array}{l}\text { Workplace social media will } \\
\text { be useful in my job }\end{array}$ & \\
\hline & \multirow{3}{*}{ Actual Use } & $\begin{array}{l}\text { My company has social } \\
\text { media to help staff } \\
\text { communicate with each } \\
\text { other at work. }\end{array}$ & \\
\hline & & $\begin{array}{l}\text { I often use workplace social } \\
\text { media to obtain work- } \\
\text { related information and } \\
\text { knowledge }\end{array}$ & \\
\hline & & $\begin{array}{l}\text { What is your frequency of } \\
\text { usage of workplace social } \\
\text { media }\end{array}$ & \\
\hline \multirow{3}{*}{$\begin{array}{l}\text { Media } \\
\text { Synchronicity } \\
\text { Theory }\end{array}$} & \multirow{3}{*}{ Performance } & $\begin{array}{l}\text { I always perform better } \\
\text { when I use the social media } \\
\text { system for work }\end{array}$ & \multirow{3}{*}{$\begin{array}{c}\text { Dennis et al. } \\
2008\end{array}$} \\
\hline & & $\begin{array}{l}\text { Using the system increases } \\
\text { my performance }\end{array}$ & \\
\hline & & $\begin{array}{l}\text { Knowledge I gain makes me } \\
\text { perform better }\end{array}$ & \\
\hline \multirow{5}{*}{$\begin{array}{l}\text { Social Capital } \\
\text { Theory }\end{array}$} & \multirow{3}{*}{ Trust } & $\begin{array}{l}\text { Given their track record I } \\
\text { see no reason to doubt my } \\
\text { colleagues competence }\end{array}$ & \multirow{5}{*}{$\begin{array}{l}\text { Cao et al. } \\
2012\end{array}$} \\
\hline & & $\begin{array}{l}\text { I believe that colleagues I } \\
\text { seek information from on } \\
\text { the company social media } \\
\text { are dedicated professionals }\end{array}$ & \\
\hline & & $\begin{array}{l}\text { It is easier for me to seek } \\
\text { information from my } \\
\text { colleagues using company } \\
\text { social network }\end{array}$ & \\
\hline & \multirow[t]{2}{*}{$\begin{array}{c}\text { Explicit } \\
\text { Knowledge }\end{array}$} & $\begin{array}{l}\text { I learned written knowledge } \\
\text { about the technology } \\
\text { effectively from my } \\
\text { colleagues }\end{array}$ & \\
\hline & & I learned business manuals & \\
\hline
\end{tabular}




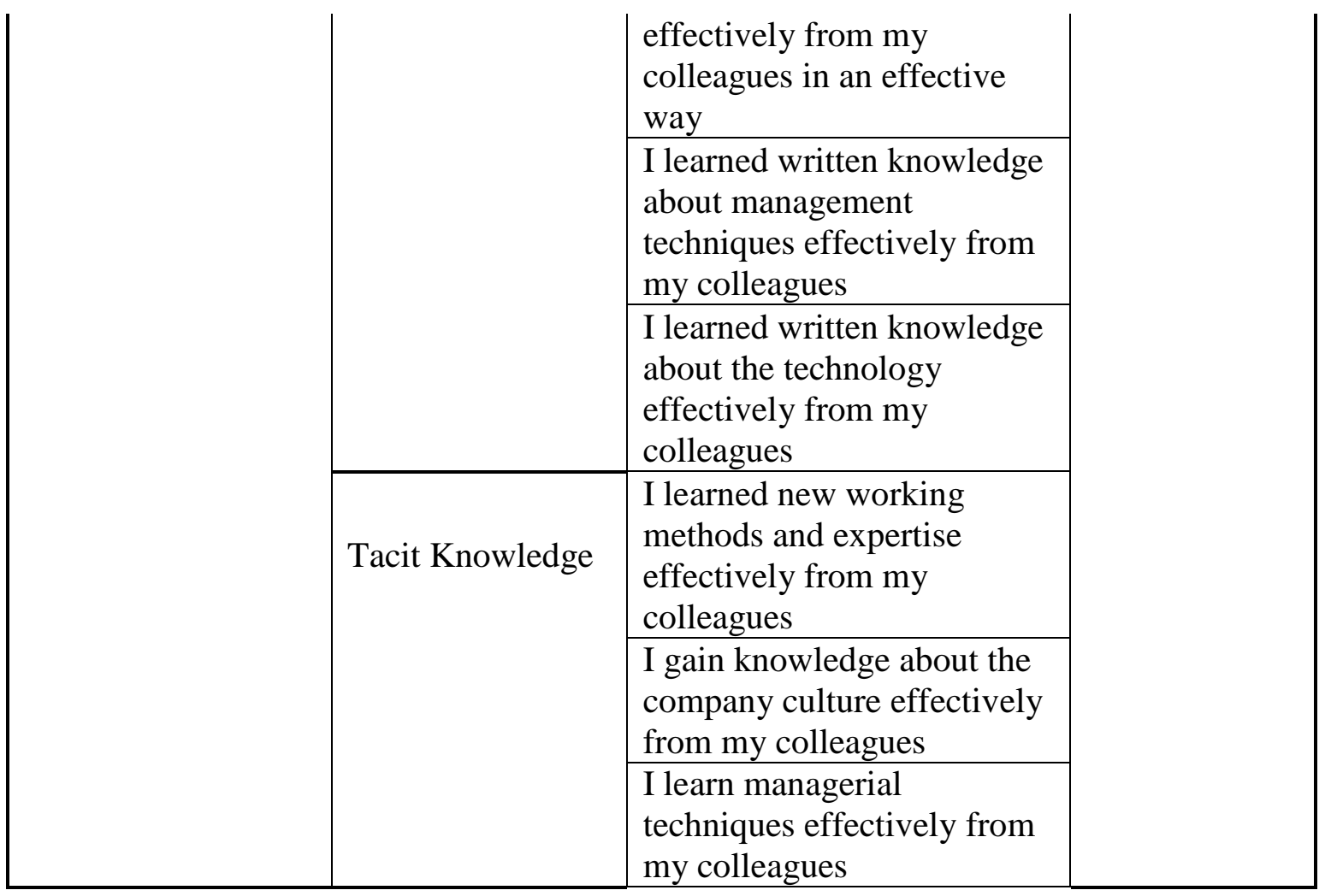

